\title{
Effect of mulching, spacing and intercropping of green gram (Vigna radiate) on growth, yield and quality of turmeric (Curcuma longa L.)
}

\author{
PARKASH SINGH SIDHU*, GURMEET SINGH DHILLON AND AMARDEEP SINGH BRAR \\ Krishi Vigyan Kendra, BATHINDA(PUNJAB) INDIA \\ (Email : psidhu8813@gmail.com)
}

\begin{abstract}
An experiment was conducted during Kharif season of 2011-12 to study the effect of mulching, spacing and intercropping of green gram (Vigna radiate) on growth, yield and quality of turmeric (Curcuma longa L.). The soil of experimental field was categorized as loamy-sand. The experiment was laid out in Randomized Complete Block Design (RCBD) with four replications and eleven treatments. The results indicates the rate of increase in plant height was higher up to 120 days after planting, there after the plant height increasing rate slowed down. Maximum plant height $74.7 \mathrm{~cm}$ was observed in treatment $T_{10}$ where inter row spacing of turmeric was $37.5 \mathrm{~cm}$ and mulch was applied as compared with other treatments. The number of tillers was maximum under turmeric + green gram intercropping systems with mulching at inter row spacing of $60 \mathrm{~cm}$ in turmeric crop. The data revealed that the sole turmeric with mulching treatment $\left(\mathrm{T}_{2}\right)$ produced maximum fresh rhizome yield $(210.0 \mathrm{q} / \mathrm{ha})$, dry rhizome yield $(63.1 \mathrm{q} / \mathrm{ha})$ and processed yield $(57.8 \mathrm{q} / \mathrm{ha})$ as compared to other intercropping treatment combinations with or without mulch application. Turmeric intercropped with green gram $(30 \mathrm{~cm}$ inter row spacing in turmeric) produced $(205.9 \mathrm{q} / \mathrm{ha})$ fresh rhizome yield closely followed by sole turmeric with mulching $(210.0 \mathrm{q} / \mathrm{ha})$. The curcumin content and oil content was not influenced by intercropping, spacing and mulching that is observed from experimental study. Turmeric intercropped with green gram at inter row spacing of 30 $\mathrm{cm}$ is a good option.
\end{abstract}

Key Words : Turmeric, Green gram, Mulching, Intercropping, Spacing

View Point Article : Sidhu, Parkash Singh, Dhillon, Gurmeet Singh and Brar, Amardeep Singh (2016). Effect of mulching, spacing and intercropping of green gram (Vigna radiate) on growth, yield and quality of turmeric (Curcuma longa L.). Internat. J. agric. Sci., 12 (1) : 90-94.

Article History : Received : 01.12.2015; Revised : 09.12.2015; Accepted : 21.12.2015

\footnotetext{
* Author for correspondence
} 